\title{
Changes in land use in Eastern Surabaya, Indonesia, and their impact on coastal society and aquaculture
}

\author{
D. A. Safitri ${ }^{1,2} \bowtie$, L. A. Bespalova ${ }^{1}$, F. Wijayanti ${ }^{3,4}$ \\ ${ }^{1}$ Southern Federal University, Rostov-on-Don, Russia; e-mail: dikadede@gmail.com \\ ${ }^{2}$ Universitas 17 Agustus 1945 (UNTAG) Surabaya, Surabaya, Indonesia \\ ${ }^{3}$ Ural Federal University, Ekaterinburg, Russia; e-mail: febry.ie008@gmail.com \\ ${ }^{4}$ Universitas Negeri Malang, Malang, Indonesia
}

\begin{abstract}
Indonesia is an archipelago country which has a large number of coastal areas, including Surabaya City. This part of the country, in particular its eastern areas, was affected by changes in land use - more land is now occupied by farms and residential areas. Another important type of land use in Surabaya is the ponds used for fish farming. This research aims to prove that the change of land use in Surabaya affects the socio-economy of the coastal area. This research uses the quantitative approach and descriptive statistic method. It shows that the increase in the number of ponds in Surabaya has not affected the growth in the number of fishermen while the amount and the value of fish production increased significantly due to marine fishing. Since most of the ponds in Surabaya are managed traditionally, they are unable to ensure a high output. Therefore, the majority of the community of Parmubayain the east coast of Surabaya would like to change the function of ponds but are impeded to dos o by the legal regulations due to the special status of this area. Consequently, the optimal use of ponds in Surabaya would be to train fishermen, fish farmers, and representatives of other related professions.
\end{abstract}

\section{KEYWORDS}

land use, ponds, fish farming, fishermen, economic value of fish production

\section{FOR CITATION}

Safitri D. A., Bespalova L. A., Wijayanti F. (2019) Changes in land use in Eastern Surabaya, Indonesia, and their impact on coastal society and aquaculture. R-economy, 5(4), 198-207. doi: 10.15826/recon.2019.5.4.020

\section{Влияние распределения земельных участков на прибрежное общество и аквакультуру в Восточной Сурабаи}

\author{
Д. А.Сафитри ${ }^{1,2} \bowtie$, Л. А. Беспалова ${ }^{1}$, В. Фебри ${ }^{3,4}$ \\ ${ }^{1}$ Южный федеральный университет, Ростов-на-Дону, Россия \\ ${ }^{2}$ Университет 17 августа 1945 (УНИТАГ), Сурабая, Индонезия \\ ${ }^{3}$ Уральский федеральный университет, Екатеринбург, Россия \\ ${ }^{4}$ Университет Негери Маланг, Маланг, Индонезия
}

\begin{abstract}
АННОТАЦИЯ
Индонезия - страна-архипелаг с обширной акваторией, поэтому, большинство районов здесь - прибрежные, одним из них является прибрежная зона города Сурабая. Структура землепользования изменяется здесь наиболее значительно в восточной части. На это изменение указывает увеличение площади земель, занятых фермерскими хозяйствами и селитебными зонами. Изменения заключаются в увеличении количества рыболовных прудов в Сурабае, которые становятся вторым по величине площади территории видом землепользования в Сурабае, после селитебного. Распределение земель должно трансформировать структуру рабочих мест и рыбохозяйственное производство. Данное исследование направлено на доказательство того, что изменение землепользования в Сурабае влияет на социально-экономическую обстановку в прибрежной зоне. Данное исследование проведено с использованием количественного подхода и описательного статистического метода. Согласно результатам исследования в Сурабае землепользование, связанное с рыбоводными прудами, не повлияло на рост численности рыбаков, тем не менее, количество и стоимость рыбной продукции значительно увеличиваются. Кроме того, обработка данных показала, что вылов рыбы Сурабаи в основном приходится на море, а не на пруды, это обстоятельство обусловлено традиционным использованием прудов, и вылов рыбы из большинства прудов в Сурабаи незначителен. Поэтому большая часть общины Пармубая рассчитывает изменить вид землепользования на территориях, используемых для прудов, но это не соответствует правительственным постановлениям относительно заповедной зоны. Следовательно, оптимально использование прудов в Сурабае в целях обучения рыболовному мастерству, разведению рыбы, ведения деятельности по разведению пресноводных рыб и многих других.
\end{abstract}

() D. A. Safitri, L. A. Bespalova, F. Wijayanti, 2019

\section{КЛЮЧЕВЫЕ СЛОВА}

землепользование, пруды, рыбохозяйственное производство, рыбаки, экономическая ценность рыбопродукции

\section{ДЛЯ ЦИТИРОВАНИЯ}

Safitri D. A., Bespalova L. A., Wijayanti F. (2019) Changes in land use in eastern Surabaya, Indonesia, and their impact on coastal society and aquaculture. R-economy, 5(4), 198-207. doi: 10.15826/recon.2019.5.4.020 


\section{Introduction}

A quarter of the world's fish production is controlled by the Association of Southeast Asian Nations (ASEAN) countries. According to the ASEAN $^{1}, 4$ out of 10 ASEAN countries are among the ten largest global fish producers. These four countries are Indonesia, Thailand, Viet Nam, and the Philippines. Based on the total output, Indonesia ranks second largest fish producer in the world after China ${ }^{2}$. In other words, Indonesia is leading the way in fish production in ASEAN with total aquaculture of 23,200,000 metric tons in 2016. Indonesia is an archipelago with an area of 5.8 million $\mathrm{km}^{2}$, which consists of vast territorial waters and territorial waters of 3.1 million $\mathrm{km}^{2}$, the Exclusive Economic Zone (EEZ) of 2.7 million $\mathrm{km}^{2}$, a coastline of $80,791 \mathrm{~km} \mathrm{[1].} \mathrm{Of} \mathrm{the} 67,439$ villages in Indonesia, approximately 9,261 villages can be described as coastal villages [2].

Taking into account all of the above it is not surprising that in 2016, Indonesia reached the level of total fishery production of 23.2 million metric tons. While the output of capture fisheries reaches more than 6.5 million metric tons or $28.3 \%$ of the total fishery output, from the economic perspective, the amount of land owned by a producer is an important production factor [3]. It will affect production, particularly in the agricultural sector [4]. Unsurprisingly, Indonesia's vast water area is an essential factor in fisheries production [5]. However, as the data in Table 1 illustrates, in 2016,

\footnotetext{
${ }^{1}$ Fisheries, where to invest? Retrieved from http://investasean.asean.org/index.php/page/view/fisheries

${ }^{2}$ Globefish highlights a quarterly update on world seafood markets. Retrieved from http://www.fao.org/3/ca4185en/ ca4185en.pdf
}

Indonesia experienced a slight decline in fisheries production in comparison with 2015 , which made Indonesia try to optimize its fishery resources.

A way to increase fishery output is to change the land use in Surabaya. Surabaya is the capital of the province of East Java. Although Surabaya is a coastal city, its capture fisheries income is not substantial. These conditions encourage Surabaya to increase its aquaculture. A method to increase the output of fishery production is changing the land use to ponds. According to Landsat's remote sensing data, changes in land use in Surabaya have happened mainly in East Surabaya, particularly in the coastal areas.

According to the Spatial Plan for 2002-2029 (Rencana Tata Ruang Wilayah or RTRW) - the planning program for long-term development of Surabaya, most of the area in East Surabaya is used for housing, education, trade, and services, protected against nature and industry. Open space in the region of East Surabaya is occupied by ponds and mangrove forests. Furthermore, Jihan [6] studied land use in East Surabaya and identified such types as housing (residential area), ponds, shrubs, educational facilities, government services, trade areas, health facilities and so on. In the district of Sukolilo, there are some changes in land use, as the land that used to be occupied by fishponds is now turning into residential area. An opposite process is happening in East Surabaya, where the land is reclaimed to create ponds [6].

Sobirin researched land cover change in Surabaya for the years of 1994, 2000, and 2011 (using the method of remote sensing) [7]. The results of the analysis included several classifications of land cover water bodies (rivers, reservoirs, etc.),

Capture fisheries production (metric tons) in ASEAN, 2014-2016

Table 1

\begin{tabular}{|r|l|r|r|r|r|r|r|}
\hline \multirow{2}{*}{ No } & \multirow{2}{*}{ Country } & \multicolumn{2}{|c|}{ Total fisheries production (metric tons) } & \multicolumn{2}{|c|}{ Capture fisheries production (metric tons) } \\
\cline { 3 - 8 } & & $\mathbf{2 0 1 4}$ & $\mathbf{2 0 1 5}$ & $\mathbf{2 0 1 6}$ & $\mathbf{2 0 1 4}$ & $\mathbf{2 0 1 5}$ & $\mathbf{2 0 1 6}$ \\
\hline 1 & Indonesia & $20,900,000$ & $22,400,000$ & $23,200,000$ & $6,530,407$ & $6,739,658$ & $6,584,419$ \\
\hline 2 & Vietnam & $6,048,983$ & $6,207,514$ & $6,420,471$ & $2,694,641$ & $2,757,314$ & $2,785,940$ \\
\hline 3 & Philippines & $4,587,385$ & $4,503,067$ & $4,228,906$ & $2,249,780$ & $2,154,908$ & $2,027,992$ \\
\hline 4 & Myanmar & $2,934,806$ & $2,970,100$ & $3,090,034$ & $1,970,550$ & $1,970,470$ & $2,072,390$ \\
\hline 5 & Thailand & $2,567,898$ & $2,429,956$ & $2,493,154$ & $1,670,035$ & $1,501,318$ & $1,530,583$ \\
\hline 6 & Malaysia & $1,989,740$ & $2,003,019$ & $1,992,258$ & $1,468,726$ & $1,496,054$ & $1,584,371$ \\
\hline 7 & Cambodia & 745,310 & 751,193 & 802,450 & 625,255 & 608,193 & 629,950 \\
\hline 8 & Lao PDR & 168,597 & 158,600 & 180,750 & 60,237 & 62,635 & 70,915 \\
\hline 9 & Singapore & $6,695,323$ & $8,161,294$ & $7,346,361$ & 1,433 & 1,265 & 1,234 \\
\hline 10 & Brunei Darus- & $3,897,07$ & $4,353,14$ & $14,239,63$ & 3,186 & 3,370 & 13,292 \\
\hline
\end{tabular}

Source: World Bank Data. Retrieved from https://databank.worldbank.org/reports.aspx?source=2\&series=ER.FSH.CAPT. MT\&country=\# 
inland water (ponds), dry land agriculture, wetland farming, settlements, industry, etc. Ashazy studied the vegetation cover in East Surabaya in a buildable area, graveyard, yard, fields, ponds, and others [8]. In East Surabaya, most of the land is covered by rice fields and ponds. In the years of 2002 and 2006, the land cover changed [9]. The results showed that there are eight categories of land cover, including ponds, roads, rivers, industry and warehousing, buildings, vegetation, mangrove forest, and abandoned fields [9]. According to experts, the prevailing type of land use is ponds $[6 ; 7 ; 9]$.

Remote sensing data show that the land use in East Surabaya corresponds to the Spatial Plan (RTRW). The ponds were located in the districts of Mulyorejo, Sukolilo, Rungkut, and Gunung Anyar. It happens because the fourth region has a considerable fishery potential and also because it located in a protected area, which means that it is better protected from land conversion.

For this reason, Surabaya government the project of establishing fishing villages: (1) Tambak wedi(Swedi) fishing village in Tambak Wedi Kelurahan Kenjeran District; (2) Cumpat fishing village in the Kedung Cowek Kelurahan Bulak district; and (3) Kejawan fishing village in Sukolilo Kelurahan Bulak District.Apart from fishing, the local communities engage in other fishing related activities such as management and transportation of production, sale and processing of fish. These activities are indicated by the increasing income of fishers each year. The official statistical data (Badan Pusat Statistik -BPS) in 2007 demonstrated that the income of fishers in Surabaya is Rp 4,481,003 every month, and in 2017 reached Rp 10,800,000.

Fisheries production in Surabaya divided into marine fisheries and inland fisheries production. Ponds in Surabaya, give the number of the output of fishery but not much. Based on the data from the official statistical information, in 2005, the total of marine fishery production was 9,227.00 tons, and the output of inland fisheries (ponds) was 8,825 tons. In 2016, marine fishery production was 10,578.30 tons, and the production of inland fisheries (ponds) was 6,915.03 tons. In 2017, the marine fish production was $8,416.60$ tons, and the production of inland fisheries (ponds) was 6.798 tons. These data show that the production of inland fisheries of the ponds was decreasing each year. Pond areas do not contribute significantly to the total output of inland fisheries. Therefore, this study aims to find out the effect of land allocation (ponds) on the socio-economic situation in local fishing communities of East Surabaya.

\section{Literature review}

\section{Definition of the term 'land use'}

Di Gregorio and Jansen define land cover as the observed biophysical cover on the earth's surface. It includes all types of vegetation and human structures that cover the land surface [10]. Jansen (2006) states that "the term land use has different meanings across disciplines" and that those different perspectives may all be valid. It also terms of socio and economic purpose [11]. Batista and Silva proposed a new way of land use mapping [12]. Additional information regarding the human activities on land or the presence of specific elements in the landscape has to be taken into account [12]. Numerous factors determine land use. First of all, biophysical factors enhance or constrain land uses (climate, topography, soil, water). Other factors include cultural context, local traditions, institutional, and political aspects [11]. Finally, the demographic and economic dynamics may drive demand for particular services and commodities, which in turn influence changes in land-use [12].

\section{Land use in Surabaya}

The JICA Study Team (2009) prepared a report on land use in Surabaya: $5.11 \mathrm{~km}^{2}(1.6 \%)$ are used for agriculture; $9.63 \mathrm{~km}^{2}$, agriculture (non-irrigation); $37.16 \mathrm{~km}^{2}(11.4 \%)$, for ponds; $127.17 \mathrm{~km}^{2}(39.0 \%)$, residential area; $14.92 \mathrm{~km}^{2}$ (4.6\%), commercial area; $27.89 \mathrm{~km}^{2}(8.5 \%)$, industrial production; $18.78 \mathrm{~km}^{2}(5.8 \%)$, forests, mangrove forests and swamps; $23.23 \mathrm{~km}^{2}(7.1 \%)$, public facilities; $27.81 \mathrm{~km}^{2}(8.5 \%)$, green space and recreation; $7.33 \mathrm{~km}^{2}$ (2.2\%), water; $27.23 \mathrm{~km}^{2}$ $(8.3 \%)$, vacant land; $0.02 \mathrm{~km}^{2}(0.0 \%)$, other purposes [13]. The study explained that residential purpose is the number one land use in Surabaya, followed by the allocation of pond land. The research conducted by Viv Djanat Prasita showed that in some locations, land-use changes have occurred [14]. Research in 1996-2015 with remote sensing data shows that there has been a change in land use, namely conservation land (e.g., mangrove forests) were turned into pond land and vice versa, principally in the East Surabaya area. This condition agrees with the BPS data: the area of ponds in 1996 was 673 hectares, and in 2015 
it was 3,139.66 hectares, which means that it increased by $2,466.66$ hectares [15].

According to Rosytha, in Surabaya the problems of land use reside primarily in the conversion of mangrove lands into settlements and aquaculture zones [16]. The mangrove area, which starts to be used as a pond area, is larger than the coastal and river areas. The transfer of land functions that occur in mangrove areas into pond areas is an activity that can improve the community's economy. The land conversion, however, does not take into account the sustainability of the ecological functions of the coast and small islands. This conservation can result in changes in mangrove function. Ponds that are increasingly large compared to mangrove areas on the coast or rivers can increase abrasion, which may occur during high tides. Additionally, land conversion to ponds will open up areas and can increase habitat fragmentation between coastal, mangrove, and river areas. Land clearing and fragmentation of mangrove land into fragments or patches of ponds can also affect the fauna of the mangrove [16].

Based on several studies that we have described above, it can be concluded that the land in Surabaya ismostly occupied by settlements and ponds. Most new ponds in Surabaya are created in East Surabaya, in Gunung Anyar District, Rungkut District, and Sukolilo District. We conducted a field check in Gunung Anyar sub-district dominated by ponds and mangroves. The ponds in the area are mostly traditionally managed ponds. Moreover, some ponds are not developed due to the bad quality of roads, which impedes access to them. Moreover, some of ponds do not produce large quantities of fish, and the ponds are intentionally left blank (not given fish seeds too) and the rest are non-production ponds (dry ponds see Figure 1).

\section{Research methodology}

This quantitative approach in this study is used to determine the impact of the land-use change in Surabaya on socio-economy: the life of fishermen's community (social aspect) and fisheries production (economic aspect) [17; 18].

This research focuses on the case of Surabaya, Indonesia. Surabaya is one of the coastal cities in Indonesia, it has 12 coastal districts and 24 coastal villages. The development of land use has an impact on shoreline changes, which, in its turn, has a socio-economic impact on coastal communities. The area of Surabaya in 1996 was $326.40 \mathrm{~km}^{2}$, and in 2017 it increased to $350.54 \mathrm{~km}^{2}$ by about 24.14 $\mathrm{km}^{2}$. As the figure below illustrates, there has been a change in the total area in Surabaya.

Based on the remote sensing data, there was an increase in the area in East Surabaya, as more lands were added such as ponds and residential districts. New ponds appeared in East Surabaya in districts Kalisari and Keputih (see Figure 2). According to the BPS data, pond area for 1996 is 673 hectares while for 2017 of 2,470.88 hectares. This area increased by 1797.88 hectares. Furthermore, there has been a steady growth in population in Surabaya. In 1996, there were 2,344,520 people living in Surabaya, and in 2017 this figure was $3,074,883$, that is, there was a $23.75 \%$ increase in the population. Meanwhile, in coastal areas, there were 993,840 people in 2015 (497,336 men and 496,504 women), the population increased by 536,971 or 7.53 percent in 2017.

Figure 2 was created with the help of ArcGIS software and illustrates the changes in the coastal area of Surabaya.
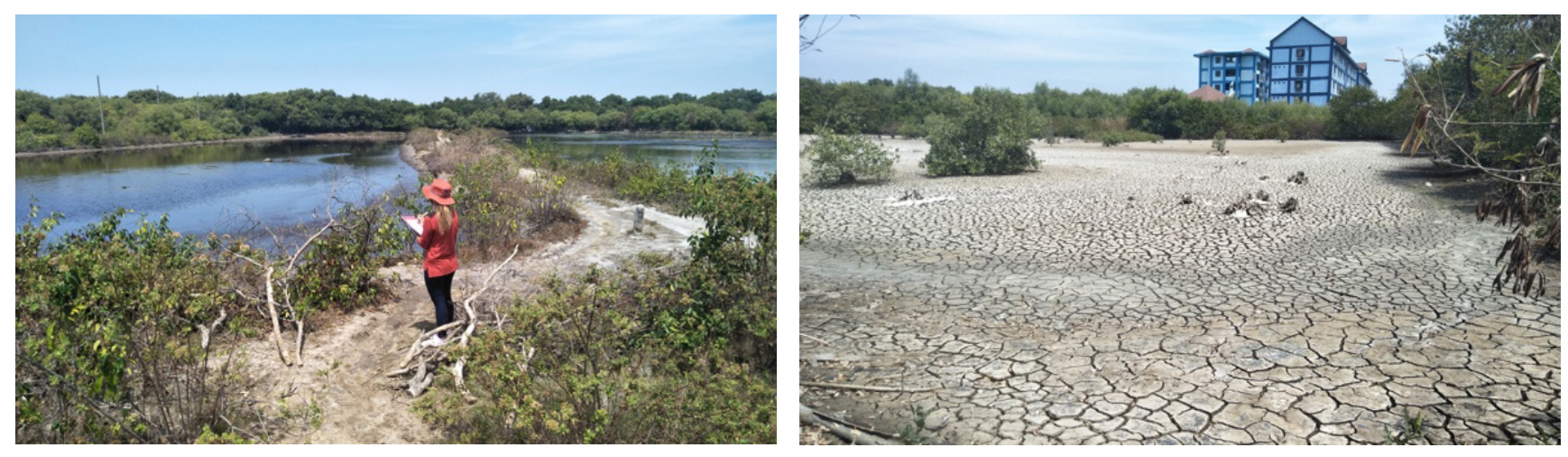

Figure 1. Condition of Pond Land in East Surabaya, one of the pond was in dry condition

(the right picture)

Source: Authors' collection 


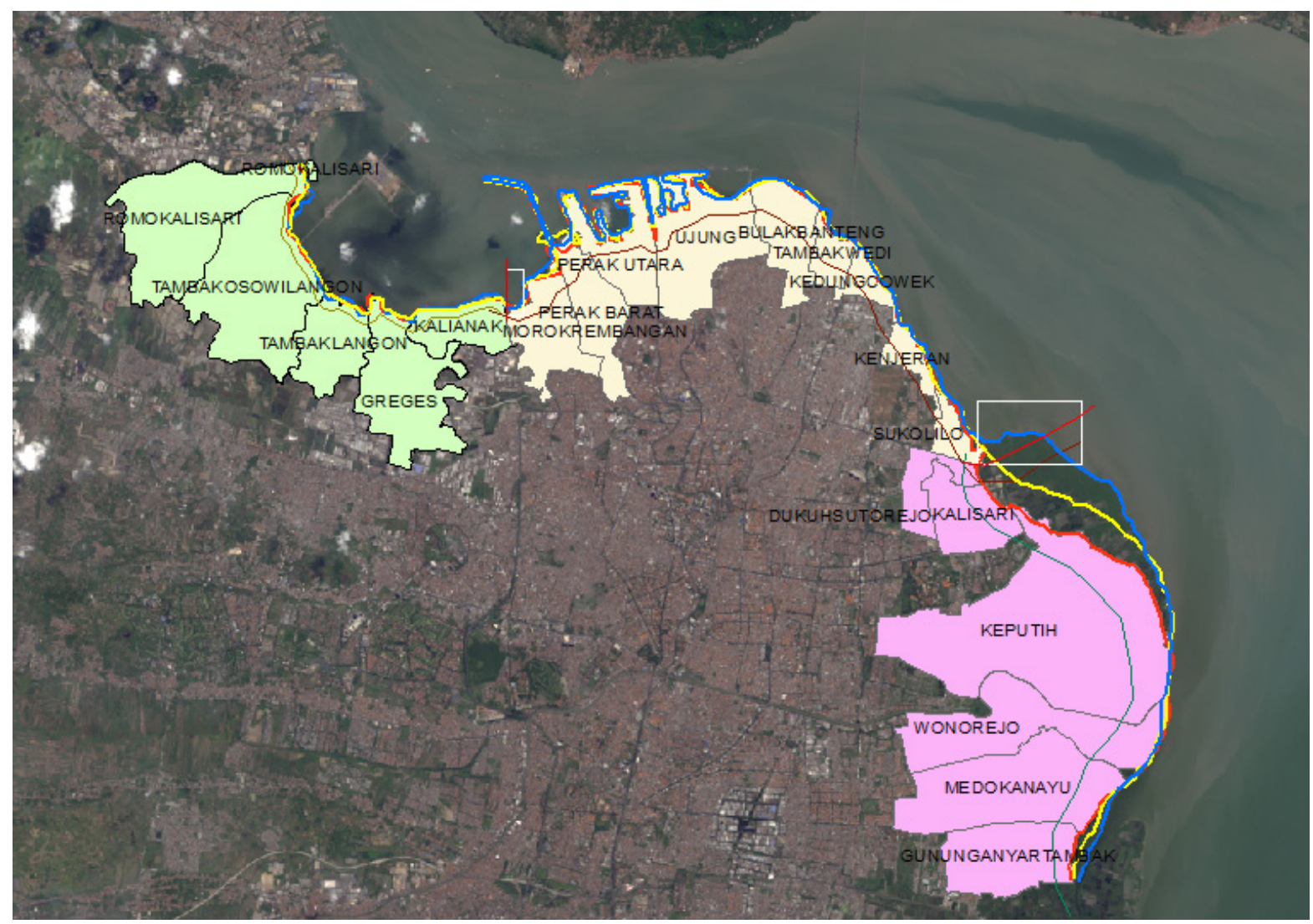

Figure 2. Map for changing of land use in Surabaya Source: Authors' file with ArcGIS program

The research uses primary and secondary data. The primary data were obtained through observation in coastal areas with photo documentation (for validating the changes of the area), while the secondary data were obtained from research literature and local government agencies.

\section{Results and discussion}

\section{Problems and condition of capture fisheries in Surabaya}

The development of capture fisheries in Indonesia so far has not been successful. As Table 1 shows, there was a decline from 2015 to 2016. This decline was due to several problems faced by Indonesian fishermen. These problems are as follows [19]:

(1) the weak management system of capture fisheries business and weak mastery of appropriate technologies resulting in a low level of production;

(2) competition in inter-regional water land use as a result of the increasing number of inhabitants in coastal areas;

(3) ongoing overfishing in some areas;
(4) the increase and scarcity of fuel, which increasingly burdens fishers to go to sea;

(5) high rates of illegal fishing,resulting in state losses, and an increasingly rapid decline in fisheries and marine resources;

(6) damage to aquatic ecosystems as a result of overexploitation and natural disasters;

(7) overlapping authority in granting permits and regulations that do not provide a conducive climate for fisheries investment;

(8) inadequate technologies of handling and processing fish production, resulting in a low quality, added value, and competitiveness of fishery products;

(9) unsafe methods of product handling and processing;

(10) limited fisheries infrastructure,insufficient capital, inadequate coordination and institutions [19].

Meanwhile, capture fisheries activities in Surabaya have been going on for a long time. The problem that has to be dealt with at the current stage is fishers who live near the coast of the Surabaya, are fishing in the waters of Surabaya with a simple fishing gear. Their catches are generally 
sold in the local market and some are directly distributed to hotels through mediators (tengkulak).

Surabaya fishermen have been fishing around the Madura Strait for many years. Fish are caught in Surabaya as well as in other areas such as Probolinggo, Brondong, and Lamongan [20].

\section{Pond conditions in Surabaya}

Ponds in Surabaya are still managed traditionally. Consequently, the arrangement of ponds and the pond infrastructure are always irregular. Traditional management has several impacts, one of which is that the pond quality is not optimal (unproductive). Moreover, fisheries are in need of modern equipment, for example, water pumps. Some cases of providing pond water pumps have several impacts in several areas, and this is related to the existence of groundwater drilling and polluting the environment around the pond.

During the dry season, most fisheries ponds in Surabaya change their function to become salt ponds. Some fishermen think that instead of their ponds being unproductive, their fishing grounds should be transformed into salt ponds. Nevertheless, the productive value of salt is not very good, so the amount of fishery production has decreased. Switching the function of ponds is a way for fishers to survive. Moreover, by creating large fisheries output, ponds in Surabaya are also used for recreational fishing.

The data from the Fisheries and Maritime Affairs of East Java Province show that there are several types of fish products such as live fish, fresh fish and processed fish. There are two types of fish products in Surabaya, they are fresh (raw) and processed fish. The total production of fresh product types is 3,700,974 tons; processed fish, 140,037 tons; so the total production of fisheries in Surabaya is $3,841,011$ tons. The sale value of fisheries production in Surabaya is $R p 175,634,207,369$. [21]

\section{Analysis of the amount and value of fisheries production in Surabaya}

According to the official data, there are two main sources of fisheries production, namely marine fisheries and freshwater fisheries (such as reservoirs, rivers, ponds). For more than 20 years (1996-2017), fish production in Surabaya has experienced its ups and downs. The total fish production in 1996 was 13,442 tons while in 2013, it was $23,274.17$ tons. After 2013, fishery production declined. Compared with the production data in 1996 and 2017, the number of production increased. Our calculations of fish productions in Surabaya use the official data (see Table 2) [15;22], the linear equation value of $y=104.23 x-192,152$ and the regression value of $R^{2}=0.0545$ (see Figure 3 ).

The decline in the amount of fishery production in Surabaya is one of the reasons for the donations from neighboring cities. Furthermore, other problems are caused by fishermen's lack of capital to go to sea to cover the costs of fuel or charter boats. Moreover, fishermen need extra training and financial support from the government (e.g. loans).

Table 2

Sea and Freshwater Fish Production in Surabaya for 1996-2017

\begin{tabular}{|r|r|}
\hline Year & Sea and Freshwater Fish Production (Tons) \\
\hline 1996 & 13,422 \\
\hline 2005 & 18,483 \\
\hline 2006 & 18,441 \\
\hline 2007 & $16,791.88$ \\
\hline 2008 & $17,455.4$ \\
\hline 2009 & $18,326.7$ \\
\hline 2010 & 19,049 \\
\hline 2011 & $16,231.95$ \\
\hline 2012 & $16,029.25$ \\
\hline 2013 & $23,274.17$ \\
\hline 2014 & $15,285.34$ \\
\hline 2015 & $14,954.15$ \\
\hline 2016 & $18,692.73$ \\
\hline 2017 & $16,576.83$ \\
\hline
\end{tabular}

Source: Badan Pusat Statistik Provinsi Jawa Timur. Retrieved from https://jatim.bps.go.id/publication/download.html?nrbvfeve=OTk5OWI3MjdkMzE2YzAwN$\underline{\text { mVlMmZkN2U3\&xzmn=aHR0cHM6Ly9qYXRpbS5i- }}$ cHMuZ28uaWQvcHVibGljYXRpb24vMjAxOC8wOC8xNi85OTk5YjcyN2QzMTZjMDA2ZWUyZmQ3ZTcvcHJvdmluc2ktamF3YS10aW11ci1kYWxhbS1hbmdrYS0yMDE4Lmh0bWw\%3D\&twoadfnoarfeauf=MjAyMC0wMSOwMyAxMjoyODoyOA\%3D\%3D

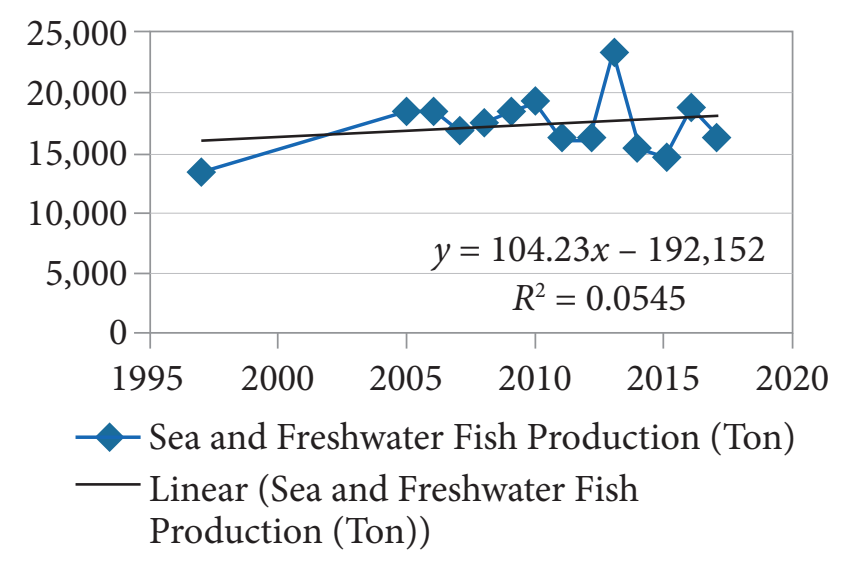

Figure 3. Chart of total production of fisheries catch in Surabaya 
The amount of marine fisheries production in 2012 was 7039.16 tons, and in 2017 it increased by 8416.6 tons (see Table 3) [22]. Over the past five years, the production increased by 1377.44 tons. The value of linear equation for marine fisheries production is $y=496.79 x-$ 992,944 and the regression value is $R^{2}=0.4073$ (see Figure 4). The production of marine fisheries in Surabaya has not increased too much because the boats used by Surabaya fishermen mostly use sailboats and outboard motorboats (usually the type of a small boat is 5GT in size). The catchment area of Surabaya fishermen's sea fisheries is in the Madura Strait, Tanjung Perak, and Sidoarjo areas.

Table 3

Sea Fish Production for 2012-2017

\begin{tabular}{|r|r|}
\hline Year & \multicolumn{1}{|c|}{ Sea fish production (Tons) } \\
\hline 2012 & $7,039.16$ \\
\hline 2013 & $6,927.63$ \\
\hline 2014 & $7,291.45$ \\
\hline 2015 & $6,840.06$ \\
\hline 2016 & $10,578.3$ \\
\hline 2017 & $8,416.6$ \\
\hline
\end{tabular}

Source: Badan Pusat Statistik Kota Surabaya. Retrieved from https://surabayakota.bps.go.id/publication/download. $\underline{\text { html? nrbvfeve=MzVkZTc2ZjE5MzM4ZTNlY2Q0NDViOD- }}$ $\underline{\text { M4\&xzmn=aHR0cHM6Ly9zdXJhYmF5YWtvdGEuYnBzLm- }}$ dvLmlkL3B1YmxpY2F0aW9uLzIwMTgvMDgvMjEvMzVkZTc2ZjE5MzM4ZTNIY2Q0NDViODM4L2tvdGEtc3VyYWJheWEtZGFsYW0tYW5na2EtMjAxOC5odG1s\&twoadfnoarfeauf=MjAyMC0wMS0wMyAxMjozMDowMQ\%3D\%3D

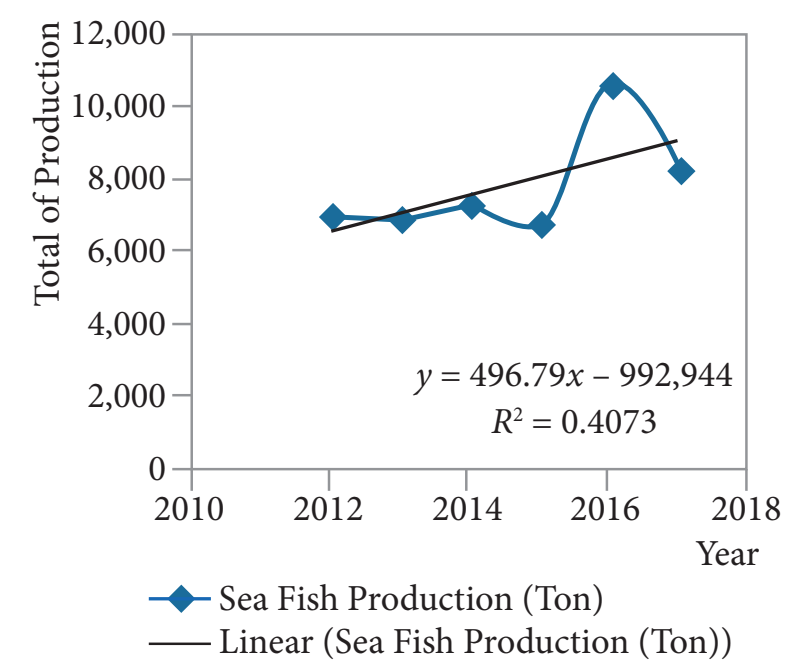

Figure 4. Chart of production of the catch of marine fisheries in Surabaya

Land in East Surabaya is increasingly used for residential purposes and ponds. In 1996, ponds in Surabaya were 673 hectares, and in 2017 it increased sharply by $2,470.88$ hectares, which means an increase of $1,797.88$ hectares [15; 22]. According to the Surabaya City Environment Department's report of 2016, the group of fish farmers in Surabaya included 15 groups with a total of 781 members. The most numerous group of fish farmers is the Roh Kelem Farmer Group, with 132 members [23].

The number of freshwater fishery catches production in Surabaya has decreased over the last five years by 837.86 tons (see Table 4 ). According to BPS data in 2012, it was $8,998.09$ tons, and in 2017 it was $8,160.23$ tons [22]. This freshwater fishery catches come not only from ponds, but also from other reservoirs such as rivers and ker$a m b a$ - traditional cages used for fish farming in Indonesia [24]. The value of linear equation for fresh water fish production is $y=-131 x+272,192$ and the regression value is $R^{2}=0.4073$ (see Figure 5).

Table 4

Production of Fresh Water Fish (other reservoirs such as rivers and keramba) (Ton)

\begin{tabular}{|r|r|}
\hline Year & Production of Fresh Water Fish (Tons) \\
\hline 2012 & $8,998.09$ \\
\hline 2013 & $8,371.39$ \\
\hline 2014 & $7,924.94$ \\
\hline 2015 & $8,114.09$ \\
\hline 2016 & $8,176.43$ \\
\hline 2017 & $8,160.23$ \\
\hline
\end{tabular}

Source: Badan Pusat Statistik Kota Surabaya. Retrived from https://surabayakota.bps.go.id/publication/download. $\underline{\text { html? nrbvfeve }=\text { MzVkZTc2ZjE5MzM4ZTNlY2Q0NDViOD- }}$ M4\&xzmn=aHR0cHM6Ly9zdXJhYmF5YWtvdGEuYnBzLmdvLmlkL3B1YmxpY2F0aW9uLzIwMTgvMDgvMjEvMzVkZTc2ZjE5MzM4ZTNIY2Q0NDViODM4L2tvdGEtc3VyYWJheWEtZGFsYW0tYW5na2EtMjAxOC5odG1s\&twoadfnoarfeauf=MjAyMC0wMS0wMyAxMjozMDowMQ\%3D\%3D

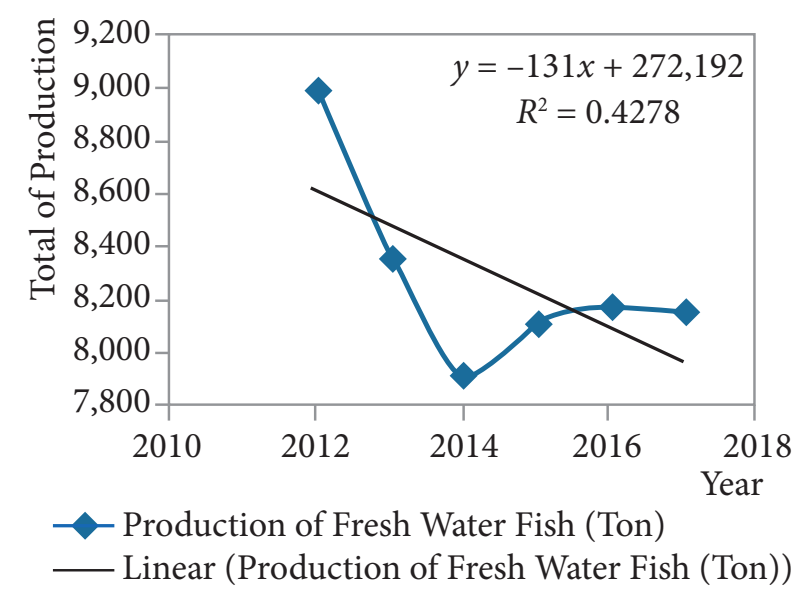

Figure 5. Chart of production catch of freshwater fisheries in Surabaya 
The number of freshwater fishery catches production in Surabaya has decreased over the past ten years (2005-2017), by 2,026.32 tons (see Table 5). According to the BPS data in 2005, it was 8825 tons, while in 2017 it was $6,798.68$ tons. The value of linear equation for marine fisheries production is $y=-190.54 x+390,906$ and the regression value is $R^{2}=0.7166$ (see Figure 6). One of the issues was that ponds in Surabaya are still managed in traditional and not always optimal ways. In the dry season, most fisheries ponds in Surabaya change their function to become salt ponds.

Table 5

Fish Production from Pond (Ton)

\begin{tabular}{|r|r|}
\hline Year & Fish Production from Pond (ton) \\
\hline 2005 & 8,825 \\
\hline 2006 & 8,573 \\
\hline 2007 & $7,886.15$ \\
\hline 2008 & $8,198.9$ \\
\hline 2009 & $8,608.7$ \\
\hline 2010 & $9,043.3$ \\
\hline 2011 & $7,923.84$ \\
\hline 2012 & $7,593.18$ \\
\hline 2013 & $6,906.1$ \\
\hline 2014 & $6,542.09$ \\
\hline 2015 & $6,785.15$ \\
\hline 2016 & $6,915.03$ \\
\hline 2017 & $6,798.68$ \\
\hline
\end{tabular}

Source: Badan Pusat Statistik Kota Surabaya. Retrived from https://surabayakota.bps.go.id/publication/ download.html? nrbvfeve $=$ MzVkZTc2ZjE5MzM4ZTNlY2Q0NDViODM4\&xzmn=aHR0cHM6Ly9zdXJhYmF5YWtvdGEuYnBzLmdvLmlkL3B1YmxpY2F0aW9uLzIwMTgvMDgvMjEvMzVkZTc2ZjE5MzM4ZTN1Y2Q0NDViODM4L2tvdGEtc3VyYWJheWEtZGFsYW0tYW5na2EtMjAxOC5odG1s\&twoadfnoarfeauf=MjAyMC0wMS0wMyAx$\underline{\text { MjozMDowMQ\%3D\%3D }}$

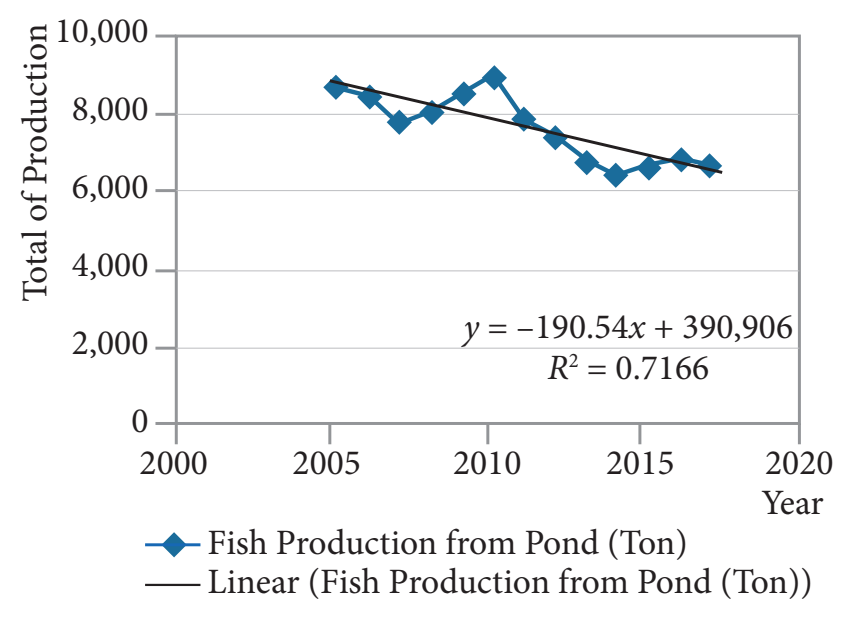

Figure 6. Chart of production catch of freshwater fisheries in Surabaya
Permadi researched the potential of ponds in Surabaya, there are several reasons why freshwater catchment production has decreased [25]:

1) the ability of farmers to buy seeds that will be cultivated in ponds;

2) uncertain weather conditions;

3) traditional cultivation methods;

4) decreased water quality due to the proximity to factories or housing.

\section{Conclusion}

Changes in land use to ponds in Surabaya have an impact on coastal communities. There are two types of ponds in Surabaya, namely fish ponds and salt ponds. With two kinds of fishery catch production in Surabaya, namely the marine catch fisheries and freshwater catch fisheries (ponds, reservoirs, rivers). Fishery catch production in Surabaya increases every year. Unsurprisingly, from 1996 to 2017, a growth in the amount of fisheries production and the production value was tenfold, although the number of fishers reduced by 1,806 people. The amount of output in 1996-2017 increased by $3,134.83$ tons, and the production value increased by $R p 242,971,338,000$. One issue is that fish production from ponds decreased over ten years (2005-2017) by 2026.3 tons. Remote sensing data show that more and more land is now occupied by ponds in East Surabaya, but this trend is not conducive to the development of fish farming in the area.

The majority of fish production in Surabaya comes from sea fishing while freshwater production is decreasing due to unproductive fish ponds. Therefore, some people who are members of Parmubaya region on the east coast of Surabaya complain about wanting to change their ponds to other types of land use. However, this plan is hindered by the rules of the area, which has the status of a protected or conservation area. Further field studies are needed to investigate and monitor the use of land in coastal areas of Surabaya. Further research might also include interviews with coastal citizens to find out more about the conditions of social economy. It is also necessary to investigate the question of whether the coastal communities in Surabaya consist of indigenous inhabitants or migrants.

The synergy between government, society, and community in East Surabaya is necessary. For example, to provide fishers with income, it is first necessary to train them. The training should include how to catch fish, the system of irriga- 
tion, how to sell, process and cook fish. Many people in Parmubaya did not want to manage their ponds because their ponds are unproductive, the government gave two solutions, first solution is managing the ponds as conservation area which will accompanied by the government.
Second solution is land acquisition by the government ${ }^{3}$.

\footnotetext{
${ }^{3}$ Protes Tekait Lahan ke DPRD Surabaya, Petani Tambak Pamurbaya Diberi Dua Pilihan. Retrieved from https://jatim. tribunnews.com/2018/04/09/protes-tekait-lahan-ke-dprdsurabaya-petani-tambak-pamurbaya-diberi-dua-pilihan
}

\section{References}

1. Djunarsjah, E. (2004). Law of the Sea. Bandung: ITB. (In Bahasa)

2. Kusnadi (2003). The Root Of The Poverty for Fishermen. Yogyakarta: LKiS. (In Bahasa)

3. Nicholson, W., \& Snyder, C. (2008). Microeconomic Theory Basic Principles and Extensions. $10^{\text {th }}$ ed. Ohio: Thomson South-Western.

4. Berczi, A. (1981). Information as a factor of production. Business Economics, 16(1), 14-20.

5. Boto, I., Phillips, S., \& D'Andrea, M. (2013). Fish-farming: the new driver of the blue economy. Brussel: Technical Centre for Agricultural and Rural Cooperation (CTA).

6. Jihan, J. C. (2014). Analysis of Zone Change Land Use in East Surabaya based on GIS. Thesis. The Department of Geomatics Engineering Faculty of Civil Engineering and Planning. Sepuluh Nopember Institute of Technology Surabaya Indonesia. (In Bahasa)

7. Sobirin. (2015). Urban Heat Island in Surabaya. Geoedukasi, 4(2). (In Bahasa)

8. Ashazy, A. A. (2013). Analysis of Index Vegetation Using Satellite Imagery FORMOSAT-2 In Urban Areas (Case Study: East Surabaya). Jurnal TEKNIK POMITS, 10(10). (In Bahasa)

9. Putro, D. (2013). Mapping Land Use East of Surabaya Based on Remote Sensing. Thesis. Department of Science and Environmental Engineering. Airlangga University Surabaya Indonesia. (In Bahasa)

10. Di Gregorio, A., \& Jansen, L.J.M. (1998). Land cover classification system: classification concepts and user manual for software version 1. FAO. Rome.

11. Jansen, L.J.M. (2006). Harmonization of land use class sets to facilitate compatibility and comparability of data across space and time. Journal of Land Use Science. 1(2-4), 127-156.

12. Filipe Batista e Silva. (2011). Land Function: Origin and Evolution of the Concept. Journal Cadernos Curso De Doutoramento Em Geografia Flup.

13. JICA. (2009). JICA study to Formulate the spatial Plan of GERBANG KERTOSUSILA (GKS). (In Bahasa)

14. Viv Djanat Prasita and friends. (2019). Assessment of the mangrove protected area in the Eastern Coast of Surabaya. Eco. Env. \& Cons. 25 (July Suppl. Issue).

15. Badan Pusat Statistik Provinsi Jawa Timur. (1997). Province of East Java in Numbers. (In Bahasa)

16. Rosytha, A. (2016). Impact Study for the Development of Settlements in the Coastal Region of East Surabaya. Jurnal AGREGAT, 1(1). (In Bahasa)

17. Creswell, J. W. (2012). Educational Research: Planning, Conducting, and Evaluating Quantitative and Qualitative Research, $4^{\text {th }}$ ed. Boston: Pearson Education, Inc.

18. Magilvy, J. K., \& Thomas, E. (2009). A First Qualitative Project: Qualitative Descriptive Design for Novice Researchers. Journal Compilation, 298-300.

19. Ismuryandi, F. (2006). The Policy of the Regional Government of Situbondo Regency in the Framework of Regional Autonomy in the Field of Fisheries. Thesis. Institute of Agriculture Bogor Indonesia. (In Bahasa)

20. Milasari, V. N. (2011). Policy Management of Fisheries in Surabaya, East Java. Thesis. Institute Of Agriculture Bogor Indonesia. (In Bahasa)

21. Dinas Perikanan dan Kelautan Provinsi Jawa Timur. (2014). The Annual report of the Statistics of Marine, Coastal and Small Islands in East Java for 2014. (In Bahasa)

22. Badan Pusat Statistik Provinsi Jawa Timur. (2018). Province of East Java in Numbers. (In Bahasa) 
23. Dinas Lingkungan Hidup Kota Surabaya. (2016). The Biodiversity Profile of Surabaya, The Ecosystem of the Pond. (In Bahasa)

24. Badan Pusat Statistik Surabaya. (2018). Surabaya in Numbers. (In Bahasa)

25. Permadi. (2013). Sistem Informasi Geografis Potensi Produktivitas Pertambakan Di Kota Surabaya. Geographic Information Systems Potential Productivity of the Pond in the City Of Surabaya. Journal TEKNIK POMITS, 10(10). (In Bahasa)

\section{Information about the authors}

Dika Ayu Safitri - PhD student in Department of Oceanography, Southern Federal University (105/42 Bolshaya Sadovaya Str., Rostov-on-Don, 344006, Russia); Lecturer in Department of Civil Engineering, Universitas 17 Agustus 1945 (UNTAG) (Jl. Semolowaru No.45, Menur Pumpungan, Kec. Sukolilo, Kota SBY, Jawa Timur 60118, Indonesia); e-mail: dikadede@gmail.com

Liudmila A. Bespalova - Professor, Department of Oceanography, Southern Federal University (105/42 Bolshaya Sadovaya Str., Rostov-on-Don, 344006, Russia); e-mail : bespalowaliudmila@ yandex.ru

Febry Wijayanti - PhD student in Economics Department, Ural Federal University (19, Mira St., Ekaterinburg, 620002, Russia); Lecturer, Economic Development Department, Universitas Negeri Malang (5, Semarang St. Malang, 65145, Indonesia), e-mail: febry.ie008@gmail.com

ARTICLE INFO: received August 13, 2019; accepted December 9, 2019

\section{Информация об авторах}

Сафитри Дика Аю - аспирант департамента океанографии, Южный федеральный университет (344006, Россия, Ростов-на-Дону, ул. Большая Садовая, 105/42), Университет 17 августа 1945 (УНИТАГ) (60118, Индонезия, Сурабая, Семоловару, 45); e-mail: dikadede@ gmail.com

Беспалова Людмила Александровна - профессор департамента океанографии (344006, Россия, Ростов-на-Дону, ул. Большая Садовая, 105/42); e-mail: bespalowaliudmila@yandex.ru

Виджаянти Фебри - аспирант Института экономики и управления, Уральский федеральный университет (620002, Россия, Екатеринбург, Мира, 19); лектор департамента экономического развития, университет Негери Маланг (65145, Индонезия, Маланг, Семаранг, 5); e-mail: febry.ie008@gmail.com

ИНФОРМАЦИЯ О СТАТЬЕ: дата поступления 13 августа 2019 г.; дата принятия к печати 9 декабря 2019 г.

This work is licensed under a Creative Commons Attribution 4.0 International License

Эта работа лицензируется в соответствии с Creative Commons Attribution 4.0

International License 